\title{
A regional perspective for work accidents: Evaluating the amount of work accidents on a city basis by the help of multi-criteria decision- making methods
}

\author{
Aynur Kazaz*1 (D), Ikbal Erbas² iD, Ridvan Simsek ${ }^{3}$ (D) \\ ${ }^{1}$ Akdeniz University, Engineering Faculty, Civil Engineering Department, Antalya, Turkey \\ ${ }^{2}$ Akdeniz University, Faculty of Architecture, ${ }^{2}$ Department of Architecture, Antalya, Turkey
}

\begin{abstract}
Occupational accidents have become a globalized problem not only in certain countries but also all over the world. The structure of the construction sector developing in integration with technological change shaped by the necessity of meeting the human needs reaching serious dimensions emerges as a result of globalization and for this reason, it makes occupational health measures more important every passing day. Thus, the construction sector which is the leading sector with regards to the cause of occupational accidents, needs the required field works and academic studies in order to take indispensable measures and precautions in terms of occupational health and safety culture and discipline. In this study, it is aimed to evaluate the trends of occupational accidents on city basis and to obtain risk ranking. In this direction, the contributions of cities to occupational accidents have been evaluated by multi-criteria decision-making methods, which cities required the most measures in terms of occupational health and safety (OHS) have been determined and the data have been evaluated specific to the construction industry. ENTROPY weighting method has been used to determine the significance of interaction between years and occupational accident years. According to the results of PROMETHEE II, GRA and OCRA MCDM (Multi Criteria Decision Making) methods, the cities where occupational accidents are of the highest importance have been identified as Istanbul, Izmir and Ankara, respectively.
\end{abstract}

\section{Keywords}

OHS (Occupational Health and Safety); Occupational accident; MCDM (Multi Criteria Decision Making), Construction management; PROMETHEE, OCRA

Received: 15 February 2021; Accepted: 23 March 2021

ISSN: 2630-5771 (online) (C) 2021 Golden Light Publishing All rights reserved.

\section{Introduction}

Occupational accidents affecting many stakeholders, primarily the individual who had an work accident, in terms of material and moral consequences [1] ensue in major human and economic damage such as occupational disease, labour force loss, and productivity reduction [2].

* Corresponding author

Email: akazaz@akdeniz.edu.tr
From a firm perspective, it can also have a great impact on competitiveness and the reputation of firms [3]. The fact that the construction sector, which is in a very important position in terms of staffing despite being one of the most dangerous fields of employment worldwide [4,5] and labour force potential in the world [6], having momentous risks in terms of working conditions [7] entails the 
necessity of applying OHS measures sensitively since the increase in the number of employees in the construction sector affects the increase in the number of injuries and deaths due to occupational accidents [8]. Worldwide, an average of 1.2 million people die each year due to occupational accidents [9]. Occupational accidents, which account for over 6000 deaths every day, affect the lives of approximately 2.3 million individuals worldwide [10]. Social Security institutions of the Republic of Turkey [11] refers that 1 out of every 5 occupational accidents $(20 \%)$ occurs in the construction sector and the construction sector causes about $37 \%$ fatal occupational accidents. The construction sector classified as a high-risk industry $[12,13]$ due to its high burden of occupational dangers [14] and decentralised structure [15] is a priority in matters give rise to fatal occupational accidents than other sectors [16]. The unparalleled turnout structure and dynamics of the sector adversely influence the OHS performance of the construction sector recognisedly [17]. Construction workers are 3 to 4 times more likely to encounter occupational accidents compared to other sector workers [18]. In addition, occupational safety is understood to be of critical importance, considering the construction sector range (tunnels, dams, viaducts, buildings, etc.), the necessity of production in all seasons, and the excess of non-institutionalized construction companies which generally carry on a business in the form of subcontractors [7]. This situation necessitates the evaluation of occupational accidents and suggestions for suitable solutions corresponding specific to construction sector's characteristics. Considering the literature studies conducted to evaluate work accidents' causes, work accidents depend on many factors such as employment rates in terms of gender and various age groups in employment [19], employee status (migrant, local) [20], object impact and equipment related accident [21] etc. In addition, along with the studies in which the general international causes of work accidents are determined, there are also studies in which work accidents are analysed on a country basis, for example [22-25]. City-based evaluation shows the perspective considered in this study. The use of multi-criteria decision-making methods for the analysis of occupational accidents and the sectoral evaluation of the accidents are the motivation sources of the study that addresses the gap in the literature. In the light of those mentioned, the main purpose of this study is the determination of work accident trends on city basis and to rank the work accident risk of cities.

\section{Methodology}

Studies on work accidents mainly focus on accident causes, accident statistics and accident prevention policies [26]. The fact that occupational accidents occur in many sectors, requires determining the trend of the occupational accident data group and evaluating it on the basis of each sectors. When the accidents are concentrated in a specific sector, it is necessary to manage this industry with more focus [27] and to take appropriate measures for the sector's dynamics. For this reason, the main motivation of this study is to make a city-based work accident evaluation after the compiled work accident data is evaluated by MCDM methods. Brief research framework can be summarised as follows.

Step 1.Gather the data between 2014-2019 from the Turkish Republic Social Security Institution.

Step 2.Form the decision matrix.

Step 3.Obtain the weight of the criteria by ENTROPY MCDM Method.

Step 4.Apply the OCRA, PROMETHEE and GRA MCDM Methods to the problem.

Step 5.Rank the cities and compare the results.

In the light of data collected from the Turkish Republic Social Security Institution, the proportional distribution of provinces that cause occupational accidents in 2018-2019 cumulatively is shown in Fig. 1, and the amount of occupational accidents in 7 provinces that cause the highest number of occupational accidents in this proportional distribution is shown in Fig. 2, respectively. 


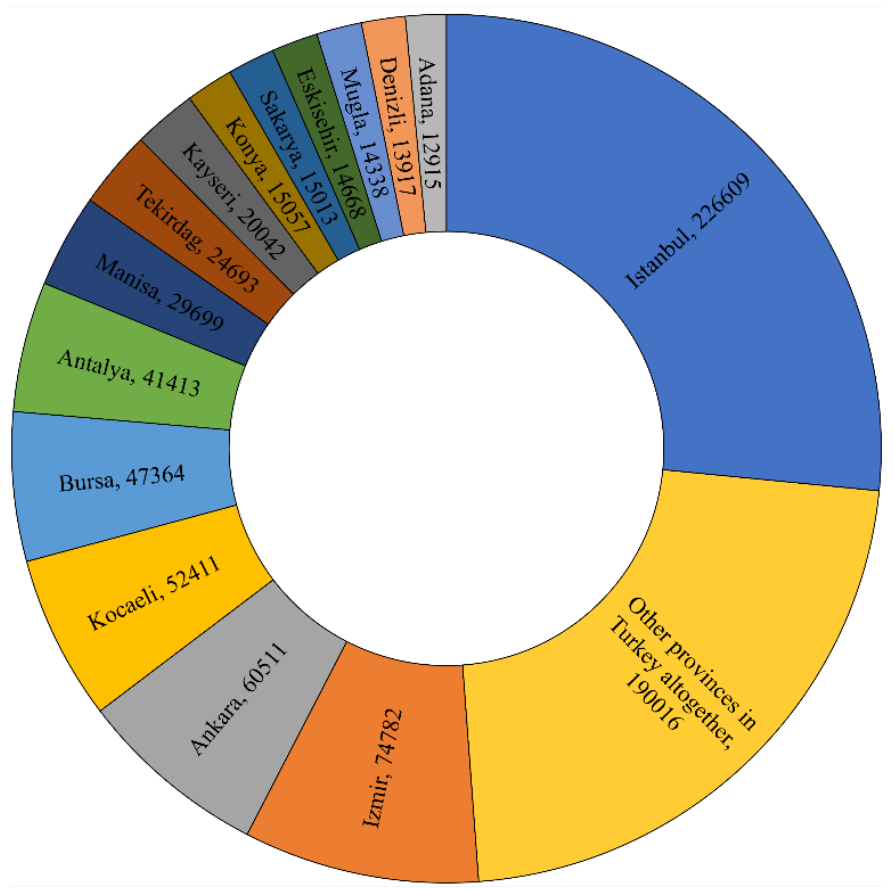

Fig. 1. The Cumulative Total Amount of Work Accidents in Turkey Between the Years 2018-2019 by Provinces

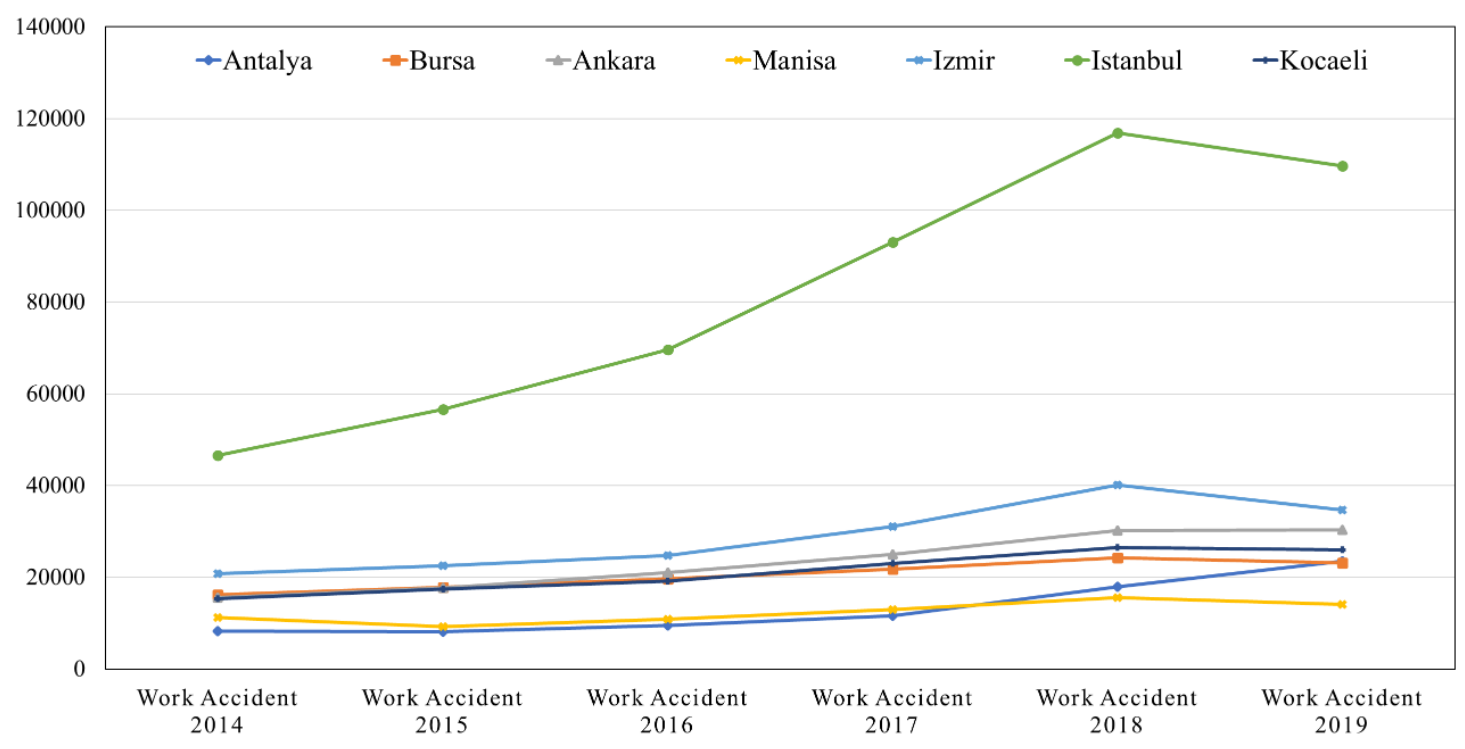

Fig. 2. The amount of occupational accidents by cities and years in 2014-2019

As can be seen in Fig. 1, the provinces with the highest cumulative contribution to occupational accidents amongst 81 provinces in Turkey in 20182019 are Istanbul, Izmir, Ankara, Kocaeli, Bursa,
Antalya and Manisa, respectively. In addition, in terms of percentage, among all provinces, Istanbul has 27\%, Izmir 9\%, Ankara 7\%, Kocaeli and Bursa $6 \%$, Antalya $5 \%$ and Manisa $3 \%$ work accident rate. 
While Istanbul provides the largest contribution in terms of the amount of accidents, it is summarized in Fig. 2 that other cities have encountered an average of 15.000-25.0000 occupational accidents per year. Cumulative evaluation of the data may cause scientific deficiencies. Evaluating the contributions to the work accident as performance over the years and obtaining the risk ranking will make a great contribution to the literature in order to produce solutions in a regional sense in terms of OHS measures. In this direction, the application of MCDM methods to OHS problems adds originality to the literature not only by looking at the amount of accidents in recent years, but also by determining the purpose of producing a compromised solution that includes all years in the solution process. The purpose of multi-criteria decision-making problems is to determine the best alternative and rank all of the alternatives but the issue to be solved in this study is occupational accidents. Therefore, the worst alternative objectively determined should be interpreted as the alternative that poses the greatest risk in terms of contribution to the work accident. In studies where independent variables such as the number of occupational accidents occurring over the years are accepted as criteria, the use of methods that allow the analysis of independent alternatives of multi-criteria decision-making methods will ensure that the solution of the problem is consistent. As a result, in this study, occupational accident performances of provinces over the years have been examined comparatively using OCRA, GRA and PROMETHEE II MCDM methods.

\subsection{The OCRA (Operational Competitiveness Rating) method}

The OCRA method, which is one of the methods used in this study which aims to determine the occupational safety performance on the basis of cities by years' interaction is a multi-criteria decision making method developed for solving performance and efficiency analysis problems [28]. Although it is not a frequently used MCDM method [29], it has yielded successful results in selection problems, performance and efficiency analysis [30]. The opportunity to make independent evaluation of alternatives [31] is another issue in its application to the problem mentioned in this study. The procedures of the OCRA method are listed as follows [31,32].

Step 1. Determine the initial decision matrix, X.

$X=\left[X_{i j}\right]_{m x n}=\left[\begin{array}{cccc}x_{11} & x_{12} & \ldots & x_{1 n} \\ x_{21} & x_{22} & \ldots & x_{2 n} \\ \ldots & \ldots & \ldots & \ldots \\ x_{m 1} & x_{m 2} & \ldots & x_{m n}\end{array}\right]$

Step 2. The aggregate performance of each alternative with respect to all non-beneficial criteria and beneficial criteria are calculated.

$$
\begin{aligned}
& \overline{I_{\mathrm{I}}}=\sum_{k=1}^{q} w_{k} \frac{\max \left(x_{i}^{k}\right)-x_{i}^{k}}{\min \left(x_{i}^{k}\right)} ;(\mathrm{i}=1,2, \ldots, \mathrm{m}) \\
& \bar{O}_{\mathrm{I}}=\sum_{h=1}^{b} w_{h} \frac{x_{i}^{h}-\min \left(x_{i}^{h}\right)}{\min \left(x_{i}^{h}\right)} ;(\mathrm{i}=1,2, \ldots, \mathrm{m})
\end{aligned}
$$

where,

q: The number of non-beneficial criteria,

$\overline{I_{\mathrm{I}}}$ : The measure of the relative performance of $\mathrm{i}$-th alternative for non-beneficial criteria

$x_{i}^{k}$ : The performance score of $\mathrm{i}$-th alternative with respect to $\mathrm{k}$-th criterion

$\mathrm{w}_{\mathrm{k}}$ : Weight of the k-th non-beneficial criterion.

$\mathrm{b}$ : The number of beneficial criteria,

$\overline{O_{\mathrm{I}}}$ : The measure of the relative performance of $i$-th alternative for beneficial criteria

$\mathrm{w}_{\mathrm{h}}$ : Weight of the h-th beneficial criterion.

Step 3. Determine the linear preference rating for beneficial and non-beneficial criteria

$\overline{\overline{I_{\mathrm{I}}}}=\overline{I_{\mathrm{I}}}-\min \left(\overline{I_{\mathrm{I}}}\right)$

$\overline{\bar{O}_{\mathrm{I}}}=\overline{O_{\mathrm{I}}}-\min \left(\overline{O_{\mathrm{I}}}\right)$

Step 4. Calculate overall preference ratings of competitive alternatives

$P_{i}=\overline{\overline{I_{\mathrm{I}}}}+\overline{\overline{O_{\mathrm{I}}}}-\min \left(\overline{\overline{I_{\mathrm{I}}}}+\overline{\overline{O_{\mathrm{I}}}}\right)$

\subsection{The GRA (Grey Ratio Analysis) method}

GRA method being one of the most popular methods used to analyse various relationships between discrete data sets and make decisions in 
multiple attribute situations [33], also which is a classification, rating and decision-making technique, developed by J. Deng in 1982 [34] and has been successfully applied in the solution of many multi-criteria decision making problems [3541]. In addition, [42] used the GRA method for prioritizing the cities in Turkey according to facility location and [38] used to measure occupational health and safety performance. One of the reasons for using the GRA method in this study is that the GRA method takes into account the correlation between the alternative and the ideal alternative in order to create alternative sequences [43] by using existing data [44], since the correlation between years of work accident and the choice of the alternative taking this correlation into account is very essential. The ranking procedure of this method can be summarized by the following steps $[45,46]$.

Step 1. Determine the initial decision matrix, develop normalised decision matrix by normalized value $r_{i j}$

$r_{i j}=\frac{x_{i j}}{\max \left(x_{i j}\right)} ; \begin{aligned} & \mathrm{i}=1,2, \ldots, \mathrm{m} \mathrm{j}=1,2, \ldots, \mathrm{n} \\ & (\text { For beneficial criteria) }\end{aligned}$

$r_{i j}=\frac{\min \left(x_{i j}\right)}{x_{i j}} \quad \begin{aligned} & \mathrm{i}=1,2, \ldots, \mathrm{m} \mathrm{j}=1,2, \ldots, \mathrm{n} \\ & \text { (For non-beneficial criteria) }\end{aligned}$

Step 2. Identify the reference series R0 and form the distance matrix

$R_{0}=r_{01}, r_{02}, \ldots, r_{0 n}$

$\delta_{i j}=r_{0 j}-r_{i j}$

where

$r_{0 j}=\max _{j} r_{i j}, \mathrm{j}=1,2, \ldots, \mathrm{n}$

The distance matrix $\Delta$ can be formed as:

$\Delta=\left[\begin{array}{cccc}\delta_{11} & \delta_{12} & \ldots & \delta_{1 n} \\ \delta_{21} & \delta_{22} & \ldots & \delta_{2 n} \\ \ldots & \ldots & \ldots & \ldots \\ \delta_{m 1} & \delta_{m 2} & \ldots & \delta_{m n}\end{array}\right]$

Step 3. Calculate the grey relational coefficient

$\xi_{i j}=\frac{\delta \min +\zeta \delta_{\max }}{\delta_{i j}-\zeta \delta_{\max }}, \mathrm{i}=1,2, \ldots, \mathrm{m} ; \mathrm{j}=1,2, \ldots, \mathrm{n}$ where

$\zeta \delta_{\max / \min }$ : Maximum and minimum $\delta_{i j}$

$\zeta$ : Distinguishing coefficient $0 \leq \zeta \leq 1$, usually supposed 0,5

Step 4. Estimate the grey relational grade, rank the alternatives. The bigger value is the better alternative.

$\gamma_{i}=\sum_{j=1}^{n} w_{j} \xi_{i j} ; \mathrm{i}=1,2, \ldots, \mathrm{m}$

Where $w_{j}$ is the weight of the $\mathrm{j}$-th criterion $w_{j} \geq 0, \sum_{j=1}^{n} w_{j}=1$

\subsection{The PROMETHEE II (The Preference Ranking Organization Method for Enrichment of Evaluations II) method}

PROMETHEE II, being a decision aid method based on pairwise comparisons [47] and one of the members of "The Preference Ranking Organization Method for Enrichment of Evaluations" family developed by Brans and Vincke $[48,49]$ aims at classifying the alternatives according to the most preferred options [50] by including an indifference and a preference threshold [51]. PROMETHEE II method is generally used more than other PROMETHEE family members by researchers because it provides complete ranking [52]. In this study main approach is to consider the worst in terms of occupational accidents. Therefore, PROMETHEE II not only provides complete outranking but also helps to take into consideration the worst alternatives. A brief description of the PROMETHEE II method steps is as follows [5355].

Step 1. Determine the initial decision matrix, develop normalised decision matrix

$$
\begin{array}{ll}
R_{i j}=\frac{x_{i j}-\min \left(x_{i j}\right)}{\max \left(x_{i j}\right)-\min \left(x_{i j}\right)} & \begin{array}{l}
\mathrm{j}=1,2, \ldots, \mathrm{m} \\
\mathrm{j}=1,2, \ldots, \mathrm{n} \\
(\text { For beneficial criteria) }
\end{array} \\
R_{i j}=\frac{\max \left(x_{i j}\right)-x_{i j}}{\max \left(x_{i j}\right)-\min \left(x_{i j}\right)} & \begin{array}{l}
1,2, \ldots, \mathrm{m} \\
\mathrm{j}=1,2, \ldots, \mathrm{n}
\end{array} \\
\text { (For non-beneficial }
\end{array}
$$
criteria) 
Step 2. Calculate the evaluative differences for each alternative and determine the preference function. Although six types of general functions are proposed, the following function can be used to eliminate the complexity of its application to real life problems.

$D(M a-M b)=R_{i j_{a}}-R_{i j_{b}}$

$P_{j}(M a, M b)=0$ if $R_{i j_{a}} \leq R_{i j_{b}}$

$P_{j}(M a, M b)=\left(R_{i j_{a}}, R_{i j_{b}}\right)$ if $R_{i j_{a}}>R_{i j_{b}}$

Step 3. Determine the aggregated preference function, calculate the leaving (positive) and entering (negative) outranking flows

$\pi_{M a, M b}=\frac{\sum_{j=1}^{m} w_{j} x P_{j}(M a, M b)}{\sum_{j=1}^{m} w_{j}}$

$\varphi^{+}=\frac{1}{n-1} \sum_{b=1}^{m} \pi(a, b)$

$\varphi^{-}=\frac{1}{n-1} \sum_{b=1}^{m} \pi(a, b)$

where $\mathrm{n}$ is the number of alternatives

\subsection{The ENTROPY method}

The weight of selection criteria representing the relative importance of each criterion in a decision making process [56] is essential to obtain reliable results. The basic approach of the entropy algorithm is to analyse the difference between index values in the data [57]. Therefore, it is considered that relative weights to be taken from this method contributes to the solution for this study, in which the interaction between years is very fundamental. The entropy algorithm is briefly as follows $[58,59]$.

Step 1: In the Entropy method, for each criterion in the decision matrix, the criterion must be determined as beneficial or not beneficial. The decision matrix is normalized according to the type of criteria same as Eqs. (7) and (8)

Step 2: Determine entropy level for each criterion $\mathrm{E}_{\mathrm{j}}$

$E_{j}=-k \sum_{i=1}^{m} y_{i j} \ln y_{i j}$ and $0 \leq E_{j} \leq 1$
In which entropy index $k=\frac{1}{\ln (m)}$

Step 3: The weight of the criteria is determined as follows.

$w_{j}=\frac{1-E_{j}}{\sum_{j=1}^{n} 1-E_{j}}$

\section{Results and discussions}

The data sets published by Turkish Republic Social Security Institution annually between 2014 and 2019 have been brought together and the decision matrix shown in Table 1 has been developed. Within the scope of the study, occupational accidents that occurred over the years have been accepted as criteria for each city and all criteria have been determined as "cost type" since it is expected to have less occupational accidents. Cities, on the other hand, represent alternatives in the initial decision matrix.

Weights shown in Table 2 have been determined with Entropy Method which includes the determination of interaction and relative importance between years in its algorithm that aims to solve the problems having high uncertainty and less specificity.

The weights obtained were applied as weights of the criteria in the PROMETHEE, GRA and OCRA methods. Due to the principle that the article is understandable without being too detailed, only the important solution steps in the methods used in the article are given under this heading. In addition, PROMETHEE II performance differences are given in appendix 1, preference functions in appendix 2. PROMETHEE II leaving and entering flows and final rank results are shown in Table 3.

The GRA method deviation sequences are shown in Table 4, grey relation coefficients in Table 5 , grey rational grades and final ranks in Table 6, respectively.

By following the OCRA method solution steps the Table 7 is formed and final rank has been determined.

The final rankings obtained from the methods have been evaluated comparatively and are shown in figure 3 . 
Table 1. Initial decision matrix

\begin{tabular}{lcccccc}
\hline Work Accident/ City & 2014 & 2015 & 2016 & 2017 & 2018 & 2019 \\
\hline Antalya & 8255 & 8100 & 9493 & 11565 & 17930 & 23483 \\
Bursa & 16133 & 17801 & 19615 & 21743 & 24289 & 23075 \\
Ankara & 15559 & 17693 & 21041 & 24970 & 30225 & 30286 \\
Manisa & 11283 & 9285 & 10869 & 12914 & 15571 & 14128 \\
Izmir & 20814 & 22572 & 24774 & 31024 & 40164 & 34618 \\
Istanbul & 46559 & 56623 & 69637 & 93003 & 116914 & 109695 \\
Kocaeli & 15300 & 17426 & 19185 & 23065 & 26467 & 25944 \\
\hline
\end{tabular}

Table 2. Ej Results and obtained weights based on ENTROPY method

\begin{tabular}{lccc}
\hline & $\mathrm{Ej}$ & $1-\mathrm{Ej}$ & $\mathrm{Wj}$ \\
\hline 2014 & 0,919793 & 0,080207 & 0,113734 \\
2015 & 0,894287 & 0,105713 & 0,149902 \\
2016 & 0,882903 & 0,117097 & 0,166044 \\
2017 & 0,86282 & 0,13718 & 0,194522 \\
2018 & 0,861328 & 0,138672 & 0,196638 \\
2019 & 0,873653 & 0,126347 & 0,17916 \\
\hline
\end{tabular}

Table 3. PROMETHEE II results

\begin{tabular}{lcccc}
\hline & $\Phi+$ & $\Phi-$ & $\Phi(\mathrm{a})$ & Rank \\
\hline Antalya & 1,62716 & 0,76608 & 0,86108 & 2 \\
Bursa & 0,79341 & 0,24444 & 0,54897 & 4 \\
Ankara & 0,91094 & 0,36949 & 0,54145 & 5 \\
Manisa & 1,64105 & 0,01967 & 1,62138 & 1 \\
Izmir & 1,48641 & 1,40741 & 0,079 & 6 \\
Istanbul & 0 & 4,38022 & $-4,3802$ & 7 \\
Kocaeli & 0,99382 & 0,26547 & 0,72835 & 3 \\
\hline
\end{tabular}

Table 4. The GRA method deviation sequences

\begin{tabular}{lllllll}
\hline & 2014 & 2015 & 2016 & 2017 & 2018 & 2019 \\
\hline Antalya & 0,000 & 0,000 & 0,000 & 0,000 & 0,023 & 0,098 \\
Bursa & 0,206 & 0,200 & 0,168 & 0,125 & 0,086 & 0,094 \\
Ankara & 0,191 & 0,198 & 0,192 & 0,165 & 0,145 & 0,169 \\
Manisa & 0,079 & 0,024 & 0,023 & 0,017 & 0,000 & 0,000 \\
Izmir & 0,328 & 0,298 & 0,254 & 0,239 & 0,243 & 0,214 \\
Istanbul & 1,000 & 1,000 & 1,000 & 1,000 & 1,000 & 0,108 \\
Kocaeli & 0,184 & 0,192 & 0,161 & 0,141 & & 0,124 \\
\hline
\end{tabular}


Table 5. The GRA method grey relation coefficients

\begin{tabular}{lllllll}
\hline & 2014 & 2015 & 2016 & 2017 & 2018 & 2019 \\
\hline Antalya & 1,000 & 1,000 & 1,000 & 1,000 & 0,956 & 0,836 \\
Bursa & 0,709 & 0,714 & 0,748 & 0,800 & 0,853 & 0,842 \\
Ankara & 0,724 & 0,717 & 0,723 & 0,752 & 0,776 & 0,747 \\
Manisa & 0,863 & 0,953 & 0,956 & 0,968 & 1,000 & 1,000 \\
Izmir & 0,604 & 0,626 & 0,663 & 0,677 & 0,673 & 0,700 \\
Istanbul & 0,333 & 0,333 & 0,333 & 0,333 & 0,333 & 0,333 \\
Kocaeli & 0,731 & 0,722 & 0,756 & 0,780 & 0,823 & 0,802 \\
\hline
\end{tabular}

Table 6. The GRA method grey rational grades and final rank

\begin{tabular}{llllllll}
\hline & Antalya & Bursa & Ankara & Manisa & Izmir & Istanbul & Kocaeli \\
\hline $\begin{array}{l}\text { Grey Rational } \\
\text { Grade }\end{array}$ & 0,96530 & 0,77777 & 0,73973 & 0,95685 & 0,65719 & 0,33333 & 0,76904 \\
Rank & 1 & 3 & 5 & 2 & 6 & 7 & 4 \\
\hline
\end{tabular}

Table 7. The OCRA Method Results and Final Rank

\begin{tabular}{lcccccc}
\hline & $\bar{I}_{i}$ & $\overline{\bar{I}}_{i}$ & $\bar{o}_{i}$ & $\overline{\bar{o}}_{i}$ & $P_{i}$ & Rank \\
\hline Antalya & 6,190782162 & 6,190782162 & 0 & 0 & 6,190782162 & 2 \\
Bursa & 5,479342664 & 5,479342664 & 0 & 0 & 5,479342664 & 3 \\
Ankara & 5,243622414 & 5,243622414 & 0 & 0 & 5,243622414 & 5 \\
Manisa & 6,228799144 & 6,228799144 & 0 & 0 & 6,228799144 & 1 \\
Izmir & 4,733356815 & 4,733356815 & 0 & 0 & 4,733356815 & 6 \\
Istanbul & 0 & 0 & 0 & 0 & 0 & 7 \\
Kocaeli & 5,419157294 & 5,419157294 & 0 & 0 & 5,419157294 & 4 \\
\hline
\end{tabular}

-PROMETHEE $"$ GRA -OCRA

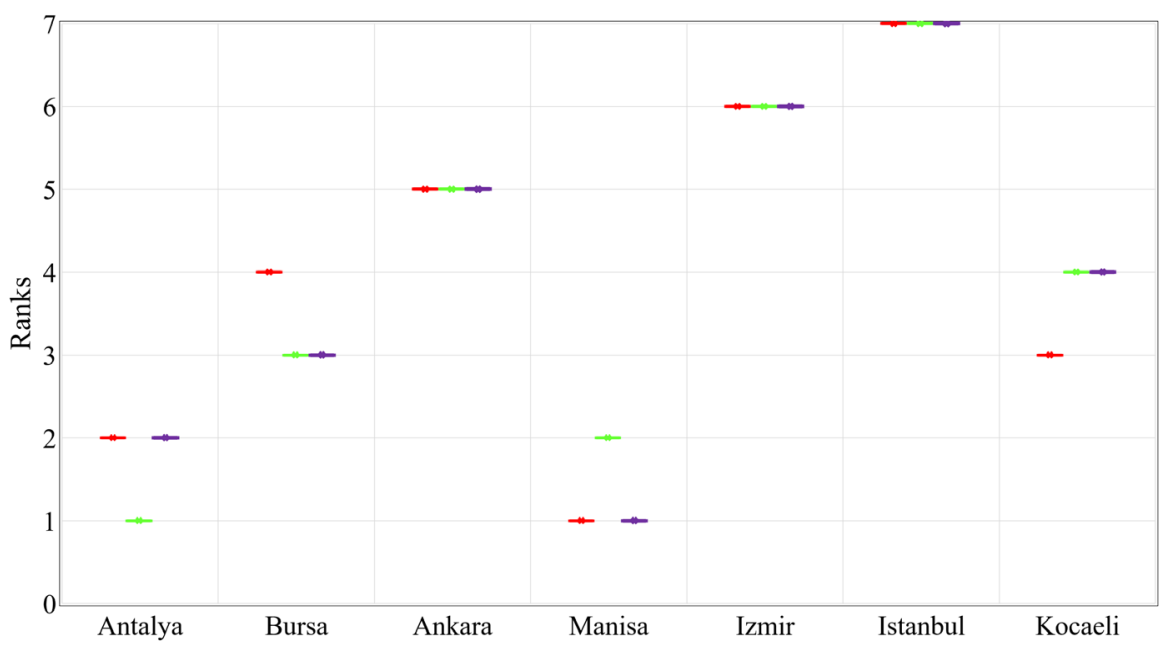

Fig. 3. Comparative results 
As it is understood from Fig. 3, the rankings obtained have been calculated similar in all 3 methods. According to these results, Istanbul, which causes the highest number of occupational accidents in the cumulative sense, has been found to have the worst performance with multi-criteria decision-making algorithms. In addition, Izmir and Ankara follow Istanbul in terms of work accident risk. However, Bursa, Manisa, Kocaeli and Antalya provinces are in different ranks in the methods used. While the province of Antalya has been determined as the second least risky province in PROMETHEE and OCRA methods, it is the least risky province according to the GRA method. It is very important to use solution algorithms generating consensual solutions in the correct analysis of cities such as Manisa, which have the potential to cause variable number of accidents. Hundreds of occupational accidents caused by mine collapses in Manisa city, especially in some years, can be considered as one of the main reasons for this variability. Therefore, it can be deduced that factors such as the mining accident that occurred in Soma district of Manisa province in 2014 caused Manisa to rank in different places in methods. From the perspective of the construction sector, Manisa should be the least risky city considering the construction capacity, number of projects and labour force potential of the construction sector. However, multi-criteria decision-making methods that incorporate the effect of deviations in their algorithm show that occupational accidents in this city is least risky amongst other cities ranked. Other provinces that show variation in the ranking are Bursa and Kocaeli. Considering the construction investment data of the city of Bursa, it is more prominent than Kocaeli, and it is a city where construction projects and construction potential are higher. In addition, the share of the construction sector among the production sectors is more important in Bursa compared to Kocaeli. However, Kocaeli province, where the industry is highly developed, is a very dynamic city where the construction sector investments have increased in recent years, has a strategic position and at the same time the construction sector is in the development trend.
Considering all these issues, it is thought that the result obtained from the algorithm of PROMETHEE focusing on the preferred criteria method is more significant. It is clear that the population factor has an effect on occupational accidents because Turkey's most populated provinces which are Istanbul, Ankara, Izmir, Bursa, Antalya are in the first places amongst other cities in terms of work accidents. In this direction, considering the population, Istanbul is likely to rank first, but Ankara, with the second largest population, has been identified less risky than Izmir. Besides, although Kocaeli's population is less than Antalya, it has been determined to be riskier. Therefore, it has been concluded that different criteria rather than population affect the results. This situation is thought to be a research topic for future studies. Additionally, Istanbul, which is Turkey's construction sector locomotive, is a city suffering from occupational accidents as a result of many numbers of construction projects, construction capacity and construction labour force. Antalya, Bursa, Kocaeli, İzmir and Ankara are other important cities where the construction sector is dynamic and has an intense work potential. From this point of view, the construction building stock concentrated in these cities and hundreds of construction projects require labour and site work. Thus, the increasing number of projects and construction increase the need for workforce. This situation plays a triggering role in the increase of work accident risk. This increased risk is the primary factor in the increase of work accidents specific to construction sector in the cities evaluated in this study.

\section{Conclusions}

The construction sector differs from other sectors with its unique working structure, which significantly increases the risk of accidents, although occupational accidents are in a very important position in all sectors. It is obvious that construction works, which are also very risky in terms of causing death, need special precautions with regards to occupational safety climate. The main purpose of this study is evaluating the trends 
of occupational accidents on city basis and to obtain risk ranking. According to the results of the study, Istanbul, Izmir, and Ankara provinces have been determined as the most dangerous provinces in terms of occupational accidents in all 3 methods. It is thought that factors such as regional construction investments, number of construction projects and dynamism of the construction sector, as well as factors related to many sectors such as labour force potential, population, industry density, number of workers, employment opportunities affect the results obtained. According to the PROMETHEE method, the 4th most risky province is Bursa, and the 5th is Kocaeli, while the opposite results have been obtained in GRA and OCRA methods. Similarly, Antalya has been identified as the least risky province in other words the 7th risky province in the GRA method, but Manisa has been ranked the least risky province in PROMETHEE and OCRA methods. The integration of occupational accidents that have occurred over the years into the multicriteria decision-making algorithm forms the basis of the original approach of the study. In this respect, this study has provided a resource for city-based performance in terms of occupational accidents by using multi-criteria decision-making methods in the field of occupational health and safety, and also for researchers conducting city-based occupational accident reduction studies. It is thought that the availability of data to be trusted on a provincial basis in terms of occupational health and safety and the resources that analyse these data are considered to be very important for future studies and subject researchers who aim to offer separate solutions for each location.

\section{Limitations}

This study was limited to some of the regional factors that affect the occurrence of city-based occupational accidents.

\section{Declaration of conflicting interests}

The author(s) declared no potential conflicts of interest with respect to the research, authorship, and/or publication of this article.

\section{References}

[1] Pehlivan T, Usta Y (2020) Establishment of an incentive system for press machine tools used in metal manufacturing industry for increasing the safety according to occupation safety. Journal of the Faculty of Engineering and Architecture of Gazi University, 35(4): 1751-1765.

[2] Kim DK, Park S (2020) Business Cycle and Occupational Accidents in Korea. Safety and Health at Work, 11(3): 314-321.

[3] Bayram M, Ünğan MC (2018) The relationships between OHS prevention costs, OHSMS practices, employee satisfaction, OHS performance and accident costs. Total Quality Management \& Business Excellence, 31(11-12): 1325-1344.

[4] Vatani J, Saraji GN, Pourreza A, Salesi M, et al. (2016) The relative costs of accidents following the establishment of the health, safety and environment management system (HSE-MS) for the construction industry in Tehran. Iranian Red Crescent Medical Journal, 18(12): e27140.

[5] Reiman A, Møller Pedersen L, Väyrynen S, Airaksinen O, et al. (2020) Multi-organisational approach to safety training: the case of a finnish safety training park. Construction Management and Economics, 38(7): 659-672.

[6] ILO (2020) Construction Sector: International Labour Organization;[07.01.2021]. Available from: https://www.ilo.org/global/industries-andsectors/construction/lang--en/index.htm

[7] Çelik T. Türkiye'de inşaat sektöründe iş kazası ve meslek hastalığı: Giresun örneği. Yüksek Lisans Tezi, Ordu Üniversitesi, 2019.

[8] Work Accidents: Turkish Republic Ministry of Family, Labour and Social Services;[07.01.2021]. Available from: http://www.guvenliinsaat.gov.tr/iskazalari.html

[9] Yegin A. İş güvenliği kültürünün iş kazalarına etkileri. Yüksek Lisans Tezi, Gedik Üniversitesi, 2015.

[10] ILO (2020) World Statistic: International Labour Organization;[07.01.2021]. Available from: https://www.ilo.org/moscow/areas-ofwork/occupational-safety-andhealth/WCMS_249278/lang-en/index.htm\#: : :text=The\%20ILO\%20estimates\% 20that $\% 20$ some,of $\% 20$ work $\% 2$ Drelated $\% 20$ illnes ses\%20annually.

[11] SSI (2020) Work Accident Data between 20072019: Turkish Republic Social Security Institution. Available from: 
http://www.sgk.gov.tr/wps/portal/sgk/tr/kurumsal/ istatistik/sgk_istatistik_yilliklari

[12] Abukhashabah E, Summan A, Balkhyour M (2020) Occupational accidents and injuries in construction industry in Jeddah city. Saudi Journal of Biological Sciences, 27(8): 1993-1998.

[13] Hossain M, Ahmed S (2018) A case study on safety assessment of construction project in Bangladesh. Journal of Construction Engineering, Management \& Innovation, 1(4): 147-156.

[14] Kiconco A, Ruhinda N, Halage AA, Watya S, et al. (2019) Determinants of occupational injuries among building construction workers in Kampala City, Uganda. BMC Public Health, 19(1): Article number 1444.

[15] Wong TKM, Man SS, Chan AHS (2020) Critical factors for the use or non-use of personal protective equipment amongst construction workers. Safety Science, 126: 104663.

[16] Zhang JY, Zi LJ, Hou YX, Deng D, et al. (2020) A C-BiLSTM approach to classify construction accident reports. Applied Science, 10(17): 5774.

[17] Uzun IM, Cebi S (2020) A novel approach for classification of occupational health and safety measures based on their effectiveness by using fuzzy Kano model. Journal of Intelligent \& Fuzzy Systems, 38(1): 589-600.

[18] Akgül M, Doğan Y (2020) Awareness analysis on occupational health and safety in the construction sector: Sample of Marmara and Central Anatolian regions. Engineering Sciences, 15(4): 159-173.

[19] Kazaz A, Ulubeyli S, Acıkara T (2016) Türk inşaat sektöründe iş kazaları ve nedenleri üzerine bir araştırma. 4. Proje ve Yapım Yönetimi Kongresi, 2016, Eskişehir, Türkiye.

[20] Adhikary P, Keen S, van Teijlingen E (2019) Workplace accidents among Nepali male workers in the Middle East and Malaysia: a qualitative study. Journal of Immigrant and Minority Health, 21(5): 1115-1122.

[21] Agumba JN, Musonda I. Occupational accidents predicting early retirement of construction workers in South Africa. In: Manu P, Emuze F, Saurin TA, Hadikusumo BHW. (ed) Construction Health and Safety in Developing Countries, Routledge, 2019, pp. 270-284.

[22] Ahmed S (2019) Causes and effects of accident at construction site: a study for the construction industry in Bangladesh. International Journal of Sustainable Construction Engineering and Technology, 10(2): 18-40.
[23] AL-Abdallat EM, Oqailan AMA, Al Ali R, Hudaib AA, et al. (2015) Occupational fatalities in Jordan. Journal of Forensic and Legal Medicine, 29: 25-29.

[24] Anaya-Aguilar R, Suarez-Cebador M, RubioRomero JC, Galindo-Reyes F (2018) Delphi assessment of occupational hazards in the wineries of Andalusia, in southern Spain. Journal of Cleaner Production, 196: 297-303.

[25] Ayob A, Shaari AA, Zaki MFM, Munaaim MAC (2018) Fatal occupational injuries in the Malaysian construction sector- causes and accidental agents. IOP Cont. Series: Earth and Environmental Science, 140: 012095.

[26] Yılmaz GK, Başağa H (2018) Assessment of occupational accidents in construction sector: A case study in Turkey. Journal of Construction Engineering, Management \& Innovation, 1(2): 95107.

[27] Lee S, Chang SR, Suh Y (2020) Developing Concentration Index of Industrial and Occupational Accidents: The Case of European Countries. Safety and Health at Work, 11(3): 266-274.

[28] Parkan C (1994) Operational competitiveness ratings of production units. Managerial and Decision Economics, 15(3): 201-221.

[29] Ulutas A (2019) Supplier selection by using a fuzzy integrated model for a textile company. Engineering Economics, 30(5): 579-590.

[30] Stanujkic D, Zavadskas EK, Liu S, Karabasevic D, et al. (2017) Improved OCRA method based on the use of interval grey numbers. Journal of Grey System, 29(4): 49-60.

[31] Madić M, Petković D, Radovanović M (2015) Selection of non-conventional machining processes using the OCRA method. Serbian Journal of Management, 10(1): 61-73.

[32] Erdoğan S, Aydın S, Balki MK, Sayin C (2020) Operational evaluation of thermal barrier coated diesel engine fueled with biodiesel/diesel blend by using MCDM method base on engine performance, emission and combustion characteristics. Renewable Energy, 151: 698-706.

[33] Ran R, Wang BJ (2015) Combining grey relational analysis and TOPSIS concepts for evaluating the technical innovation capability of high technology enterprises with fuzzy information. Journal of Intelligent \& Fuzzy Systems, 29(4): 1301-1309.

[34] Ju-Long D (1982) Control problems of grey systems. Systems \& Control Letters, 1(5): 288-294.

[35] Zhu XJ, Zhu HB, Liu DN, Zhou XZ (2020) Criteria making in role negotiation. IEEE Transaction on 
Systems, Man, and Cybernetics: Systems, 50(10): 3731-3740.

[36] Sama HR, Kosuri SVK, Kalvakolanu S (2020) Evaluating and ranking the Indian private sector banks-A multi-criteria decision-making approach. Journal of Public Affairs, 2020: e2419.

[37] Mahmoudi A, Javed SA, Liu SF, Deng XP (2020) Distinguishing coefficient driven sensitivity analysis of GRA model for intelligent decisions: application in project management. Technological and Economic Development of Economy, 26(3): 621-641.

[38] Korkusuz AY, Inan UH, Ozdemir Y, Basligil H (2020) Occupational health and safety performance measurement in healthcare sector using integrated multi criteria decision making methods. Journal of the Faculty of Engineering and Architecture of Gazi University, 35(1): 81-96.

[39] Javed SA, Mahmoudi A, Liu SF (2020) Grey absolute decision analysis (GADA) method for multiple criteria group decision-making under uncertainty. International Journal of Fuzzy Systems,22(4): 1073-1090.

[40] Ghoushchi SJ, Ab Rahman MN, Raeisi D, Osgooei $\mathrm{E}$, et al. (2020) Integrated decision-making approach based on SWARA and GRA methods for the prioritization of failures in solar panel systems under Z-information. Symmetry-Basel, 12(2): 310.

[41] Ayag Z, Samanlioglu F (2020) Fuzzy AHP-GRA approach to evaluating energy sources: a case of Turkey. International Journal of Energy Sector Management, 14(1): 40-58.

[42] Avdan E. E-waste recovery plant location selection with multi criteria decision making techniques. MSc Thesis, Pamukkale University, 2018.

[43] Awasthi A, Omrani H, Gerber P (2018) Investigating ideal-solution based multicriteria decision making techniques for sustainability evaluation of urban mobility projects. Transportation Research Part A: Policy and Practice, 116: 247-259.

[44] Altintas K, Vayvay O, Apak S, Cobanoglu E (2020) An extended GRA method integrated with fuzzy AHP to construct a multidimensional index for ranking overall energy sustainability performances. Sustainability, 12(4): 1602.

[45] Esiyok Y. Solution of personnel selection problem with multi-criteria decision techniques: An application in the media sector. MSc Thesis, Istanbul Aydin University, 2018.
[46] Kuo M-S, Liang G-S (2011) Combining VIKOR with GRA techniques to evaluate service quality of airports under fuzzy environment. Expert Systems with Applications, 38(3): 1304-1312.

[47] De Smet Y, Mareschal B, Verly C. Extending the PROMETHEE II method to continuous and combinatorial multi-objective optimization problems: a first model. IEEE International Conference on Industrial Engineering and Engineering Management, 2009, Hong Kong, China.

[48] Mareschal B, Brans JP, Vincke P. PROMETHEE: A new family of outranking methods in multicriteria analysis. ULB--Universite Libre de Bruxelles; 1984.

[49] Vincke JP, Brans P (1985) A preference ranking organization method. The PROMETHEE method for MCDM. Management Science, 31(6): 647-656.

[50] Dachowski R, Galek K (2020) Selection of the best method for underpinning foundations using the PROMETHEE II method. Sustainability, 12(13): 5373.

[51] Kangas A, Kangas J, Pykalainen J (2001) Outranking methods as tools in strategic natural resources planning. Silva Fennica, 35(2): 215-227.

[52] Peng Y, Zhang Y, Kou G, Li J, et al. (2012) Multicriteria decision making approach for cluster validation. Procedia Computer Science, 9: 12831291.

[53] Goswami SS (2020) Outranking methods: Promethee I and Promethee II. Foundations of Management, 12(1): 93-110.

[54] Pegoraro F, Santos EAP, Loures EDR, Laus FW (2020) A hybrid model to support decision making in emergency department management. Knowledge-Based Systems, 203: 106148.

[55] Wang CN, Viet VTH, Ho TP, Nguyen VT, et al. (2020) Multi-criteria decision model for the selection of suppliers in the textile industry. Symmetry, 12(6): 979.

[56] Görçün ÖF (2020) Efficiency analysis of Black sea container seaports: application of an integrated MCDM approach. Maritime Policy \& Management, 2020:1-28.

[57] Zhou JL, Wu YN, Wu CH, He FY, et al. (2020) A geographical information system based multicriteria decision-making approach for location analysis and evaluation of urban photovoltaic charging station: A case study in Beijing. Energy Conversion and Management, 205: 112340. 
[58] Emovon I, Samuel OD (2017) Prioritizing alternative solutions to power generation problems using MCDM techniques: Nigeria as case study. International Journal of Integrated Engineering, 9(3): 11-17.
[59] Wang JX, Zhai XT, Liu C, Zhang YS (2017) Determination of the threshold for extreme load extrapolation based on multi-criteria decisionmaking technology. Strojniski Vestnik: Journal of Mechanical Engineering, 63(3): 201-211.

\section{Appendix}

\section{A1. PROMETHEE II performance differences}

\begin{tabular}{|c|c|c|c|c|c|c|}
\hline D12 & 0,20567 & 0,199926 & 0,168296 & 0,124979 & 0,062747 & $-0,00427$ \\
\hline D13 & 0,190685 & 0,1977 & 0,192006 & 0,164604 & 0,121321 & 0,071186 \\
\hline D14 & 0,079052 & 0,024421 & 0,022878 & 0,016565 & $-0,02328$ & $-0,09789$ \\
\hline D15 & 0,327877 & 0,29825 & 0,254074 & 0,238943 & 0,219394 & 0,116515 \\
\hline D16 & 1 & 1 & 1 & 1 & 0,976723 & 0,902111 \\
\hline D17 & 0,183923 & 0,192198 & 0,161147 & 0,141212 & 0,084239 & 0,025752 \\
\hline D21 & $-0,20567$ & $-0,19993$ & $-0,1683$ & $-0,12498$ & $-0,06275$ & 0,004269 \\
\hline D23 & $-0,01499$ & $-0,00223$ & 0,02371 & 0,039625 & 0,058573 & 0,075455 \\
\hline D24 & $-0,12662$ & $-0,1755$ & $-0,14542$ & $-0,10841$ & $-0,08602$ & $-0,09362$ \\
\hline $\mathrm{D} 25$ & 0,672123 & 0,70175 & 0,745926 & 0,761057 & 0,757329 & 0,785595 \\
\hline D26 & 0 & 0 & 0 & 0 & 0 & 0 \\
\hline D27 & $-0,02175$ & $-0,00773$ & $-0,00715$ & 0,016233 & 0,021491 & 0,030021 \\
\hline D31 & $-0,19069$ & $-0,1977$ & $-0,19201$ & $-0,1646$ & $-0,12132$ & $-0,07119$ \\
\hline D32 & 0,014985 & 0,002226 & $-0,02371$ & $-0,03963$ & $-0,05857$ & $-0,07545$ \\
\hline D34 & $-0,11163$ & $-0,17328$ & $-0,16913$ & $-0,14804$ & $-0,1446$ & $-0,16908$ \\
\hline D35 & 0,137192 & 0,10055 & 0,062068 & 0,074339 & 0,098073 & 0,045329 \\
\hline D36 & 0,809315 & 0,8023 & 0,807994 & 0,835396 & 0,855402 & 0,830925 \\
\hline D37 & $-0,00676$ & $-0,0055$ & $-0,03086$ & $-0,02339$ & $-0,03708$ & $-0,04543$ \\
\hline D41 & $-0,07905$ & $-0,02442$ & $-0,02288$ & $-0,01656$ & 0,023277 & 0,097889 \\
\hline D42 & 0,126619 & 0,175504 & 0,145418 & 0,108414 & 0,086025 & 0,09362 \\
\hline D43 & 0,111633 & 0,173279 & 0,169127 & 0,148039 & 0,144598 & 0,169075 \\
\hline D45 & 0,248825 & 0,273829 & 0,231195 & 0,222378 & 0,242671 & 0,214405 \\
\hline D46 & 0,920948 & 0,975579 & 0,977122 & 0,983435 & 1 & 1 \\
\hline D47 & 0,104872 & 0,167776 & 0,138268 & 0,124647 & 0,107516 & 0,123641 \\
\hline D51 & 0,672123 & 0,70175 & 0,745926 & 0,761057 & 0,757329 & 0,785595 \\
\hline D52 & $-0,12221$ & $-0,09832$ & $-0,08578$ & $-0,11396$ & $-0,15665$ & $-0,12078$ \\
\hline D53 & $-0,13719$ & $-0,10055$ & $-0,06207$ & $-0,07434$ & $-0,09807$ & $-0,04533$ \\
\hline D54 & $-0,24883$ & $-0,27383$ & $-0,2312$ & $-0,22238$ & $-0,24267$ & $-0,2144$ \\
\hline D56 & 0,672123 & 0,70175 & 0,745926 & 0,761057 & 0,757329 & 0,785595 \\
\hline D57 & $-0,14395$ & $-0,10605$ & $-0,09293$ & $-0,09773$ & $-0,13515$ & $-0,09076$ \\
\hline D61 & -1 & -1 & -1 & -1 & $-0,97672$ & $-0,90211$ \\
\hline D62 & $-0,79433$ & $-0,80007$ & $-0,8317$ & $-0,87502$ & $-0,91398$ & $-0,90638$ \\
\hline D63 & $-0,80931$ & $-0,8023$ & $-0,80799$ & $-0,8354$ & $-0,8554$ & $-0,83092$ \\
\hline D64 & $-0,92095$ & $-0,97558$ & $-0,97712$ & $-0,98344$ & -1 & -1 \\
\hline D65 & $-0,67212$ & $-0,70175$ & $-0,74593$ & $-0,76106$ & $-0,75733$ & $-0,7856$ \\
\hline D67 & $-0,81608$ & $-0,8078$ & $-0,83885$ & $-0,85879$ & $-0,89248$ & $-0,87636$ \\
\hline D71 & $-0,18392$ & $-0,1922$ & $-0,16115$ & $-0,14121$ & $-0,08424$ & $-0,02575$ \\
\hline D72 & 0,021747 & 0,007728 & 0,00715 & $-0,01623$ & $-0,02149$ & $-0,03002$ \\
\hline D73 & 0,006762 & 0,005503 & 0,030859 & 0,023392 & 0,037082 & 0,045434 \\
\hline D74 & $-0,10487$ & $-0,16778$ & $-0,13827$ & $-0,12465$ & $-0,10752$ & $-0,12364$ \\
\hline D75 & 0,143954 & 0,106053 & 0,092927 & 0,097731 & 0,135155 & 0,090764 \\
\hline D76 & 0,816077 & 0,807802 & 0,838853 & 0,858788 & 0,892484 & 0,876359 \\
\hline
\end{tabular}


A2. PROMETHEE II preference functions

\begin{tabular}{|c|c|c|c|c|c|c|}
\hline & 2014 & 2015 & 2016 & 2017 & 2018 & 2019 \\
\hline D12 & 0,023392 & 0,029969 & 0,027945 & 0,024311 & 0,012339 & 0 \\
\hline D13 & 0,021687 & 0,029636 & 0,031881 & 0,032019 & 0,023856 & 0,012754 \\
\hline D14 & 0,008991 & 0,003661 & 0,003799 & 0,003222 & 0 & 0 \\
\hline D15 & 0,037291 & 0,044708 & 0,042187 & 0,04648 & 0,043141 & 0,020875 \\
\hline D16 & 0,113734 & 0,149902 & 0,166044 & 0,194522 & 0,192061 & 0,161622 \\
\hline D17 & 0,020918 & 0,028811 & 0,026757 & 0,027469 & 0,016565 & 0,004614 \\
\hline D21 & 0 & 0 & 0 & 0 & 0 & 0,000765 \\
\hline D23 & 0 & 0 & 0,003937 & 0,007708 & 0,011518 & 0,013519 \\
\hline D24 & 0 & 0 & 0 & 0 & 0 & 0 \\
\hline D25 & 0,076443 & 0,105193 & 0,123857 & 0,148043 & 0,14892 & 0,140748 \\
\hline D26 & 0 & 0 & 0 & 0 & 0 & 0 \\
\hline D27 & 0 & 0 & 0 & 0,003158 & 0,004226 & 0,005379 \\
\hline D31 & 0 & 0 & 0 & 0 & 0 & 0 \\
\hline D32 & 0,001704 & 0,000334 & 0 & 0 & 0 & 0 \\
\hline D34 & 0 & 0 & 0 & 0 & 0 & 0 \\
\hline D35 & 0,015603 & 0,015073 & 0,010306 & 0,014461 & 0,019285 & 0,008121 \\
\hline D36 & 0,092046 & 0,120266 & 0,134163 & 0,162503 & 0,168205 & 0,148869 \\
\hline D37 & 0 & 0 & 0 & 0 & 0 & 0 \\
\hline D41 & 0 & 0 & 0 & 0 & 0,004577 & 0,017538 \\
\hline D42 & 0,014401 & 0,026308 & 0,024146 & 0,021089 & 0,016916 & 0,016773 \\
\hline D43 & 0,012696 & 0,025975 & 0,028083 & 0,028797 & 0,028433 & 0,030292 \\
\hline D45 & 0,0283 & 0,041047 & 0,038389 & 0,043257 & 0,047718 & 0,038413 \\
\hline D46 & 0,104743 & 0,146241 & 0,162245 & 0,1913 & 0,196638 & 0,17916 \\
\hline D47 & 0,011927 & 0,02515 & 0,022959 & 0,024247 & 0,021142 & 0,022152 \\
\hline D51 & 0,076443 & 0,105193 & 0,123857 & 0,148043 & 0,14892 & 0,140748 \\
\hline D52 & 0 & 0 & 0 & 0 & 0 & 0 \\
\hline D53 & 0 & 0 & 0 & 0 & 0 & 0 \\
\hline D54 & 0 & 0 & 0 & 0 & 0 & 0 \\
\hline D56 & 0,076443 & 0,105193 & 0,123857 & 0,148043 & 0,14892 & 0,140748 \\
\hline D57 & 0 & 0 & 0 & 0 & 0 & 0 \\
\hline D61 & 0 & 0 & 0 & 0 & 0 & 0 \\
\hline D62 & 0 & 0 & 0 & 0 & 0 & 0 \\
\hline D63 & 0 & 0 & 0 & 0 & 0 & 0 \\
\hline D64 & 0 & 0 & 0 & 0 & 0 & 0 \\
\hline D65 & 0 & 0 & 0 & 0 & 0 & 0 \\
\hline D67 & 0 & 0 & 0 & 0 & 0 & 0 \\
\hline D71 & 0 & 0 & 0 & 0 & 0 & 0 \\
\hline D72 & 0,002473 & 0,001158 & 0,001187 & 0 & 0 & 0 \\
\hline D73 & 0,000769 & 0,000825 & 0,005124 & 0,00455 & 0,007292 & 0,00814 \\
\hline D74 & 0 & 0 & 0 & 0 & 0 & 0 \\
\hline D75 & 0,016372 & 0,015897 & 0,01543 & 0,019011 & 0,026577 & 0,016261 \\
\hline D76 & 0,092815 & 0,121091 & 0,139287 & 0,167053 & 0,175496 & 0,157009 \\
\hline
\end{tabular}




\section{A3. PROMETHEE II reference matrix}

\begin{tabular}{lcccccccc}
\hline & Antalya & Bursa & Ankara & Manisa & İzmir & İstanbul & Kocaeli & $\boldsymbol{\Phi +}$ \\
\hline Antalya & 0,000 & 0,118 & 0,152 & 0,020 & 0,235 & 0,978 & 0,125 & $\underline{\underline{1,627}}$ \\
Bursa & 0,001 & 0,000 & 0,037 & 0,000 & 0,743 & 0,000 & 0,013 & $\underline{0,793}$ \\
Ankara & 0,000 & 0,002 & 0,000 & 0,000 & 0,083 & 0,826 & 0,000 & $\underline{0,911}$ \\
Manisa & 0,022 & 0,120 & 0,154 & 0,000 & 0,237 & 0,980 & 0,128 & $\underline{1,641}$ \\
İzmir & 0,743 & 0,000 & 0,000 & 0,000 & 0,000 & 0,743 & 0,000 & $\underline{1,486}$ \\
İstanbul & 0,000 & 0,000 & 0,000 & 0,000 & 0,000 & 0,000 & 0,000 & $\underline{0,000}$ \\
Kocaeli & 0,000 & 0,005 & 0,027 & 0,000 & 0,110 & 0,853 & 0,000 & $\underline{0,994}$ \\
Ф- & $\underline{0,766}$ & $\underline{0,244}$ & $\underline{0,369}$ & $\underline{0,020}$ & $\underline{1,407}$ & $\underline{4,380}$ & $\underline{0,265}$ & \\
\hline
\end{tabular}

